\title{
cha.OPEN
}

\section{Predictors of long-term use of prescription opioids in the community-dwelling population of adults without a cancer diagnosis: a retrospective cohort study}

\author{
Audrey Béliveau MSc, Anne-Marie Castilloux MSc, Cara Tannenbaum MD MSc, \\ Philippe Vincent BPharm MSc, Cristiano Soares de Moura BPharm PhD, Sasha Bernatsky MD PhD, \\ Yola Moride PhD
}

\section{Abstract}

Background: Long-term opioid use is a known risk factor for opioid-related harms. We aimed to identify risk factors for and predictors of long-term use of prescription opioids in the community-dwelling population of adults without a diagnosis of cancer, to inform practice change at the point of care.

\begin{abstract}
Methods: Using Quebec administrative claims databases, we conducted a retrospective cohort study in a random sample of adult members ( $\geq 18 \mathrm{yr}$ ) of the public drug plan who did not have a cancer diagnosis and who initiated a prescription opioid in the outpatient setting between Jan. 1, 2012, and Dec. 31, 2016. The outcome of interest was long-term opioid use ( $\geq 90$ consecutive days or $\geq 120$ cumulative days over $12 \mathrm{mo}$ ). Potential predictors included sociodemographic factors, medical history, characteristics of the initial opioid prescription and prescriber's specialty. We used multivariable logistic regression to assess the association between each characteristic and long-term use. We used the area under the receiver operating characteristic curve to determine the predictive performance of full and parsimonious models.
\end{abstract}

Results: Of 124664 eligible patients who initiated opioid therapy, 4172 (3.3\%) progressed to long-term use of prescription opioids. The most important associated factors in the adjusted analysis were long-term prescription of acetaminophen-codeine (odds ratio [OR] 6.30, 95\% confidence interval [Cl] 4.99 to 7.96), prescription of a long-acting opioid at initiation (OR $6.02,95 \% \mathrm{Cl} 5.31$ to 6.84 ), initial supply of 30 days or more (OR $4.22,95 \% \mathrm{Cl} 3.81$ to 4.69 ), chronic pain (OR $2.41,95 \% \mathrm{Cl} 2.16$ to 2.69 ) and initial dose of at least 90 morphine milligram equivalents (MME) per day (OR 1.24, 95\% Cl 1.04 to 1.47). Our predictive model, including only the initial days' supply and chronic pain diagnosis, had area under the curve of 0.7618 .

Interpretation: This study identified factors associated with long-term prescription opioid use. Limiting the initial supply to no more than 7 days and limiting doses to $90 \mathrm{MME} /$ day or less are actions that could be undertaken at the point of care.

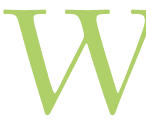

ell-known harms of long-term opioid use include substance use disorder, misuse and overdose, including overdose causing death..$^{1-7}$ Over time, Canada has seen a steady rise in opioid use disorders. ${ }^{8}$ Various interventions and policies have been implemented, although they have had limited effect on opioid-related harms. ${ }^{9}$ The number and dose of opioid prescriptions have been decreasing in Canada since 2016, ${ }^{8}$ but treatment duration increased from an average of 41.3 days in 2006 to 54.9 days in $2016 .{ }^{10}$ In the United States, $42 \%$ of patients received a supply of 30 days or more in $2017 .{ }^{11}$

Strategies to identify and prevent unnecessary long-term opioid use, as well as the close monitoring of those receiving long-term therapy, may help to mitigate opioid-related harms. In the literature on opioids, patients with and without cancer are almost always studied separately, because the factors that affect the benefits and risks of opioid use differ between these 2 groups; a recent Canadian guideline also distinguishes between the 2 populations. ${ }^{12}$

Most published studies on determinants of long-term opioid use in the population without cancer have focused on subpopulations, such as patients with traumatic injuries, ${ }^{13}$ those

Competing interests: For activities unrelated to the current study, Philippe Vincent has received an educational grant from Janssen and personal fees from Janssen, Otsuka and Proxim. As president of YolaRx Consultants, Yola Moride has served as a consultant for various opioid manufacturers, including Teva Canada Innovation and Paladin Labs. No other competing interests were declared.

This article has been peer reviewed.

Correspondence to: Yola Moride, yola.moride@umontreal.ca CMAJ Open 2021. DOI:10.9778/cmajo.20200076 
who have undergone hip arthroscopy, ${ }^{14,15}$ those with musculoskeletal disorders ${ }^{16,17}$ or veterans. ${ }^{18-21}$ In the current study, conducted in the general community-dwelling adult population without a cancer diagnosis, we aimed to identify risk factors for and predictors of long-term prescription opioid use to inform practice change at the point of care.

\section{Methods}

\section{Setting and design}

This retrospective cohort study, conducted in the province of Quebec, Canada, involved community-dwelling adults ( $\geq 18$ yr) covered by the Quebec Public Prescription Drug Insurance Plan, which includes the majority (94\%) of older people $(\geq 65 \mathrm{yr})$, all welfare recipients and residents whose medication costs are not covered by private insurance (about $43 \%$ of residents age $<65 \mathrm{yr}$ ). ${ }^{22} \mathrm{We}$ included in our analysis people without a diagnosis of cancer who initiated a prescription opioid in the outpatient setting. The study outcome was progression to long-term use of a prescription opioid over a follow-up period of 12 months.

\section{Data sources}

We used 3 administrative claims databases managed by the Régie de l'assurance maladie du Québec: beneficiary, drug dispensing and medical services. ${ }^{22}$ The beneficiary database includes sociodemographic characteristics, level of copay (which is dependent on income) and coverage periods. The dispensing database lists drugs covered by the plan (excluding in-hospital and over-the-counter medications), with each record specifying the dispensing date, drug code, number of units, dose, days' supply and prescriber's specialty; there is no information on indication. The medical services database records claims in inpatient, outpatient and emergency department settings, with diagnoses coded using the International Classification of Diseases, 9th Revision (ICD-9). ${ }^{23}$ All 3 databases can be linked through deterministic linkage using the person's health insurance number.

\section{Study population}

We obtained data for a random sample of 125000 adult members ( $\geq 18 \mathrm{yr}$ ) of the public drug plan (the maximum allowed under the data-sharing agreement) who initiated a prescription opioid between Jan. 1, 2012, and Dec. 31, 2016 (where the date of opioid initiation was considered the index date); the last follow-up ended on Dec. 31, 2017.

We applied the following inclusion criteria: absence of claims with a cancer diagnosis (ICD-9 codes 140-239.9), continuous drug plan coverage in the 12 months before and 12 months after opioid initiation, absence of methadone dispensing in the previous 12 months (which would indicate opioid use disorder) and patient alive at the end of the 12-month follow-up. Apart from cancer, we applied no exclusions based on diagnoses.

Following receipt of the sample data, we excluded patients who were admitted to hospital or long-term care for $70 \%$ or more of the follow-up period, because no inpatient dispensing data were available. We were unable to determine the flow of patients through the phases of the sample selection.

\section{Variables}

We included in the analysis all prescription opioids covered by the public drug plan, specifically morphine, codeine, hydromorphone, oxycodone, butorphanol, fentanyl, meperidine and pentazocine. We excluded methadone (because it is an indicator of an opioid use disorder), and suboxone was not covered. Because the combination product acetaminophen-codeine is available over the counter, we excluded this medication from the index opioids but assessed it in terms of the patient's history of using prescription pain medication. We used the most frequent definition of long-term opioid use found in the literature: ${ }^{15,24-27} 90$ or more consecutive days or 120 or more cumulative days over 12 months, regardless of switches. We considered prescription overlap to represent concomitant use.

We considered the following sociodemographic characteristics: age group, sex, region of residence and level of copay. As is the case for many claims databases, alcohol usage and smoking history were not available, and we were unable to perform linkage with complementary data sources. We determined overall health status using the Charlson Comorbidity Index, ${ }^{28}$ with diagnoses weighted according to the probability of death over 1 year. We considered claims in the 12 months before the index date with diagnoses of known risk factors for opioid use disorder ${ }^{29-33}$ (codes listed in Appendix 1, available at www. cmajopen.ca/content/9/1/E96/suppl/DC1), including mood disorder, schizophrenia, anxiety, other psychiatric conditions, substance use disorder and dementia, as well as previous dispensings of benzodiazepines, antipsychotics, antidepressants, analgesics (prescribed acetaminophen, acetaminophencodeine, corticosteroids, nonsteroidal anti-inflammatory drugs, gabapentinoids) and antidepressants used for pain (tricyclic antidepressants, venlafaxine, duloxetine, paroxetine, fluoxetine). Duration of past use was categorized as short-term $(<90 \mathrm{~d})$ or long-term ( $\geq 90 \mathrm{~d})$.

Given that indications were not available, we cross-linked initial opioid dispensing with diagnoses and procedures to identify those likely to be associated with acute or chronic pain. Based on expert clinical assessment (by coauthors C.T. and P.V.) and a study conducted in Ontario, ${ }^{34}$ we created the following mutually exclusive categories of inferred indications for opioid use (codes listed in Appendix 2, available at www. cmajopen.ca/content/9/1/E96/suppl/DC1): claims for surgical procedures or diagnosis related to accident or fracture made in the emergency department in the 30 days before the index date, or initial opioid prescription by a dentist; diagnosis associated with chronic pain in the 12 months before the index date (arthritis, spinal stenosis, fibromyalgia, osteoporosis, deformation of the spine, neuropathy, limb pain, neck pain); diagnosis of conditions associated with other types of pain in the 12 months before the index date (abdominal, thoracic, tendon or digestive system pain; abscess); or, in the absence of the above criteria, a hospital or emergency department claim in the 7 days before the index date, to account for in-hospital procedures not billed on a fee-for-service basis. 
Characteristics of the index opioid dispensing were product code, concomitant opioid dispensings, mode of action (short- or long-acting), duration of initial supply $(<15,15-29$ or $\geq 30 \mathrm{~d}$ ) and prescribed daily dose. Using established conversion factors (Table 1), ${ }^{10,25,34,35}$ we converted the initial daily dose prescribed into daily morphine milligram equivalents (MME/d), ${ }^{12,26,35}$ categorized as follows: $<30,30$ to $<50,50$ to $<90$, and $\geq 90 \mathrm{MME} /$ day. Opioid dosage intensity was the total MMEs divided by treatment duration, excluding the number of days in hospital.

\section{Statistical analysis}

We identified factors associated with progression to longterm prescription opioid use through multivariable logistic regression analysis, initially including all variables. Sex was considered a priori to modify the effect of age; as such, we included an interaction term.

We used the area under the receiver operating characteristic curve to determine the predictive performance of the model, ${ }^{36}$ using a threshold of greater than 0.70 to define good performance. ${ }^{37} \mathrm{We}$ developed a parsimonious predictive model using backward selection of covariables. The backward selection of variables, including the variables associated with collinearity, was automated. The aim was to identify which patients were likely to progress to long-term use of prescription opioids, based on the simplest model in a clinical setting. The final reduced model that we retained was the one with the least number of variables resulting in area under the curve greater than 0.70 .

We conducted all statistical analyses using SAS software, version 9.4 (SAS Institute Inc.).

\section{Ethics approval}

The study was approved by the Ethics Committee of Université de Montréal (no. 18-102-CERES-D).

\section{Results}

The study cohort consisted of 124664 eligible adult patients without cancer who initiated a prescription opioid in the outpatient setting, of whom 4172 (3.3\%) went on to long-term use of prescription opioids within 1 year. Patients who progressed

\begin{tabular}{|lcc|}
\hline $\begin{array}{l}\text { Table 1: Conversion factors for morphine milligram } \\
\text { equivalents }{ }^{10,25,34,35}\end{array}$ & $\begin{array}{c}\text { Amount equivalent } \\
\text { to } 30 \text { mg oral } \\
\text { morphine, mg }\end{array}$ & $\begin{array}{c}\text { Conversion to } \\
\text { morphine equivalent } \\
\text { (multiply by) }\end{array}$ \\
\hline Codeine & 200 & 0.15 \\
\hline Oxycodone & 20 & 1.5 \\
\hline Hydromorphone & 6 & 5 \\
\hline Meperidine & 300 & 0.1 \\
\hline Pentazocine & 182 & 0.165 \\
\hline Butorphanol & 4.3 & 7 \\
\hline Methadone & 10 & 3 \\
\hline
\end{tabular}

to long-term use accounted for $51.1 \%$ of the MMEs dispensed to the entire cohort during follow-up.

\section{Patient characteristics}

Patients who progressed to long-term use were older, more likely to be female and more likely to have a lower income than those with short-term use (Table 2). They also had a higher frequency of risk factors for opioid use disorder, including previous diagnosis of psychiatric disorders and dementia, and had received more psychotropic medications in the year before the index date. There was, however, no statistically significant difference in history of substance use disorder. The frequency of previous long-term use of pain medications was also higher among those with long-term use of prescription opioids. The most frequent claims preceding the initiation of a prescribed opioid among patients who progressed to long-term use were related to chronic pain (47.4\%), whereas among those with short-term use the most frequent claims were related to accident, fracture or surgery (31.2\%). Overall, $24.1 \%$ and $15.0 \%$ of those with long-term and short-term use, respectively, had no claims or claims that were not associated with acute or chronic pain.

\section{Prescribing characteristics}

Among those for whom opioids were prescribed over the long term, the mean number of days' supply over 12 months was 242.7 (standard deviation [SD] 86.6), and the mean dosage intensity was 41.5 (SD 57.4) MME/day. Among patients with short-term use, the mean number of days' supply was 10.9 (SD 15.3), and the mean dosage intensity was 36.3 (SD 23.2) MME/day.

For both groups, hydromorphone was the most frequently dispensed opioid at the index date, followed by morphine (Table 3). There were, however, important differences in mode of action. At initiation, a long-acting opioid was dispensed to $24.0 \%$ of patients who progressed to long-term use compared with $1.3 \%$ of those who had short-term use. Of patients who went on to long-term use of prescription opioids, $27.1 \%$ had obtained an initial supply of 30 days or more, compared with $2.8 \%$ of those who had short-term use. A mean initial daily dose of at least $90 \mathrm{MME}$ was also more frequent among patients who progressed to long-term use than among those without such progression $(5.7 \%$ v. $3.6 \%)$.

Family physicians accounted for the majority of prescribers, regardless of patient group. Surgeons and urologists prescribed the highest mean dose at initiation (47.6 and 42.9 $\mathrm{MME} / \mathrm{d}$, respectively) whereas family physicians prescribed the lowest mean dose (33.3 MME/d). The number of days of initial supply was highest among family physicians (mean 6.6, SD 6.7) and lowest among gynecologists (mean 3.8, SD 3.2) and dentists (mean 3.8, SD 2.5). Family physicians accounted for the majority of prescriptions with initial supply of 30 days or more $(82.5 \%)$.

As shown in Table 4, the prescription characteristics highly associated with progression to long-term use were long-acting opioid at treatment initiation, concomitant opioid 
Table 2 (part 1 of 2): Characteristics of patients with long-term and short-term use of prescription opioids

\begin{tabular}{|c|c|c|c|}
\hline \multirow[b]{2}{*}{ Characteristic } & \multicolumn{2}{|c|}{ Group; no (\%) of participants } & \multirow[b]{2}{*}{$\begin{array}{l}\text { Difference in proportion, }{ }^{*} \\
\%(95 \% \mathrm{Cl})\end{array}$} \\
\hline & $\begin{array}{l}\text { Long-term use } \\
\quad n=4172\end{array}$ & $\begin{array}{l}\text { Short-term use } \\
n=120492\end{array}$ & \\
\hline \multicolumn{4}{|l|}{ Demographic and clinical } \\
\hline \multicolumn{4}{|l|}{ Age group, yr } \\
\hline 18 to 44 & $459(11.0)$ & $35000(29.0)$ & $-18.2(-19.0$ to -17.0$)$ \\
\hline 45 to 54 & $568(13.6)$ & $16688(13.8)$ & $-0.3(-1.3$ to 0.0$)$ \\
\hline 55 to 64 & $752(18.0)$ & 20681 (17.2) & $+0.8(0.0$ to 2.1$)$ \\
\hline 65 to 74 & $851(20.4)$ & 27085 (22.5) & $-2.1(-3.3$ to -0.8$)$ \\
\hline 75 to 84 & $852(20.4)$ & $15077(12.5)$ & +7.9 (6.7 to 9.2$)$ \\
\hline$\geq 85$ & $690(16.5)$ & $5961(4.9)$ & $+11.5(10.5$ to 12.8$)$ \\
\hline \multicolumn{4}{|l|}{ Sex } \\
\hline Male & $1627(39.0)$ & $53517(44.4)$ & $-5.4(-6.9$ to -3.9$)$ \\
\hline Female & $2545(61.0)$ & $66975(55.6)$ & +5.4 (3.9 to 6.9$)$ \\
\hline \multicolumn{4}{|l|}{ Region of residence } \\
\hline Urban & $1275(30.6)$ & 39419 (32.7) & $-2.2(-3.6$ to -0.7$)$ \\
\hline Semi-urban & $1695(40.6)$ & 47768 (39.6) & +1.0 (0.0 to 2.5$)$ \\
\hline Rural & $1178(28.2)$ & 32902 (27.3) & $+0.9(0.0$ to 2.3$)$ \\
\hline Unknown & $24(0.6)$ & $403(0.3)$ & $+0.2(0.1$ to 0.5$)$ \\
\hline \multicolumn{4}{|l|}{ Socioeconomic status } \\
\hline Beneficiary of drug program (< $65 \mathrm{yr}$ ) & $853(20.4)$ & $52374(43.5)$ & $-23.0(-24.3$ to -21.7$)$ \\
\hline Welfare recipient & $942(22.6)$ & $20351(16.9)$ & $+5.7(4.4$ to 7.0$)$ \\
\hline Low income ( $\geq 65 \mathrm{yr})$ & $261(6.3)$ & $3585(3.0)$ & $+3.3(2.6$ to 4.1$)$ \\
\hline Medium income ( $\geq 65 \mathrm{yr})$ & $1297(31.1)$ & $21159(17.6)$ & $+13.5(12.1$ to 15.0$)$ \\
\hline High income ( $\geq 65 \mathrm{yr})$ & $819(19.6)$ & $23023(19.1)$ & $+0.5(0.0$ to 1.8$)$ \\
\hline \multicolumn{4}{|l|}{ Charlson Comorbidity Index } \\
\hline 0 & $2423(58.1)$ & $89623(74.4)$ & $-16.3(-17.8$ to -14.8$)$ \\
\hline 1 & $1199(28.7)$ & $23107(19.2)$ & +9.6 (8.2 to 11.0$)$ \\
\hline$\geq 2$ & $550(13.2)$ & $7762(6.4)$ & $+6.7(5.7$ to 7.8$)$ \\
\hline \multicolumn{4}{|l|}{$\begin{array}{l}\text { Claims associated with chronic or acute } \\
\text { pain (potential indications for opioid) }\end{array}$} \\
\hline Accident, fracture or surgery & $497(11.9)$ & $37546(31.2)$ & $-19.3(-20.2$ to -18.2$)$ \\
\hline Diagnosis associated with chronic pain & $1977(47.4)$ & $28886(24.0)$ & $+23.4(21.9$ to 25.0$)$ \\
\hline Other diagnosis associated with pain & $383(9.2)$ & $17054(14.2)$ & $-5.0(-5.8$ to -4.0$)$ \\
\hline $\begin{array}{l}\text { Inpatient or ED visit for unknown } \\
\text { diagnosis }\end{array}$ & $310(7.4)$ & $18909(15.7)$ & $-8.3(-9.1$ to -7.4$)$ \\
\hline Unknown potential indication & $1005(24.1)$ & $18097(15.0)$ & $+9.1(7.8$ to 10.4$)$ \\
\hline \multicolumn{4}{|l|}{ Risk factors for opioid use disorder } \\
\hline \multicolumn{4}{|l|}{ Psychiatric disorder } \\
\hline Mood disorder & $236(5.7)$ & $3976(3.3)$ & $+2.4(1.7$ to 3.1$)$ \\
\hline Schizophrenia & $192(4.6)$ & $3116(2.6)$ & $+2.0(1.4$ to 2.7$)$ \\
\hline Anxiety disorder & $283(6.8)$ & $3683(3.1)$ & +3.7 (3.0 to 4.5$)$ \\
\hline Other psychiatric disorder & $486(11.6)$ & $6127(5.1)$ & $+6.6(5.6$ to 7.6$)$ \\
\hline Dementia & $292(7.0)$ & $2148(1.8)$ & $+5.2(4.5$ to 6.0$)$ \\
\hline Substance use disorder & $113(2.7)$ & $1783(1.5)$ & $+1.2(0.7$ to 1.8$)$ \\
\hline
\end{tabular}




\begin{tabular}{|c|c|c|c|}
\hline \multirow[b]{2}{*}{ Characteristic } & \multicolumn{2}{|c|}{ Group; no (\%) of participants } & \multirow[b]{2}{*}{$\begin{array}{l}\text { Difference in proportion, }{ }^{*} \\
\%(95 \% \mathrm{Cl})\end{array}$} \\
\hline & $\begin{array}{l}\text { Long-term use } \\
\qquad n=4172\end{array}$ & $\begin{array}{l}\text { Short-term use } \\
n=120492\end{array}$ & \\
\hline \multicolumn{4}{|c|}{$\begin{array}{l}\text { Psychotropic drug dispensing in } 12 \mathrm{mo} \\
\text { before index date }\end{array}$} \\
\hline Benzodiazepines & $1958(46.9)$ & 27495 (22.8) & +24.1 (22.6 to 25.7$)$ \\
\hline Antipsychotics & $774(18.6)$ & $9426(7.8)$ & +10.7 (9.6 to 12.0$)$ \\
\hline Antidepressants & $988(23.7)$ & $13729(11.4)$ & $+12.3(11.0$ to 13.6$)$ \\
\hline \multicolumn{4}{|c|}{ Previous use of pain medications } \\
\hline \multicolumn{4}{|l|}{ NSAIDs } \\
\hline Short-term $(<90 \mathrm{~d})$ & $943(22.6)$ & 25664 (21.3) & $+1.3(0.0$ to 2.6$)$ \\
\hline Long-term ( $\geq 90 \mathrm{~d})$ & 745 (17.9) & $6835(5.7)$ & $+12.2(11.0$ to 13.4$)$ \\
\hline \multicolumn{4}{|c|}{ Prescribed acetaminophen } \\
\hline Short-term (<90 d) & $550(13.2)$ & $8968(7.4)$ & +5.7 (4.7 to 6.8$)$ \\
\hline Long-term ( $\geq 90 \mathrm{~d})$ & $983(23.6)$ & $7191(6.0)$ & $+17.6(16.3$ to 18.9$)$ \\
\hline \multicolumn{4}{|c|}{ Prescribed acetaminophen-codeine } \\
\hline Short-term $(<90 \mathrm{~d})$ & $452(10.8)$ & $7164(5.9)$ & $+4.9(4.0$ to 5.9$)$ \\
\hline Long-term ( $\geq 90 \mathrm{~d})$ & $164(3.9)$ & $335(0.3)$ & +3.7 (3.1 to 4.3$)$ \\
\hline \multicolumn{4}{|l|}{ Gabapentinoid } \\
\hline Short-term (<90 d) & $330(7.9)$ & $2990(2.5)$ & $+5.4(4.6$ to 6.3$)$ \\
\hline Long-term ( $\geq 90 \mathrm{~d})$ & $622(14.9)$ & $4219(3.5)$ & $+11.4(10.4$ to 12.5$)$ \\
\hline
\end{tabular}

dispensing during the index period, initial dose of at least $90 \mathrm{MME} /$ day and initial supply of at least 30 days. Compared with morphine, there were no differences among opioid products (except codeine, which decreased the likelihood of progression to long-term prescription of opioids). Patient characteristics significantly associated with long-term opioid use were previous claims for diagnosis associated with chronic pain and women aged 85 years or older. Previous use of pain medications was also a risk factor, especially longterm use of prescribed acetaminophen-codeine. Psychiatric diagnosis, a known risk factor for opioid use disorder, was not associated with long-term opioid use after adjustment for all other variables. Compared with recent claims for accident or fracture (associated with acute pain), all other pain diagnosis categories increased the probability of long-term use, especially chronic pain.

\section{Predictors of long-term opioid use}

The predictive model including all variables was associated with area under the curve of 0.8736 (Figure 1). The parsimonious model, which included only initial dispensing of at least 30 days' supply and a previous chronic pain diagnosis, had area under the curve of 0.7618 . The association between each variable included in the parsimonious model and long-term use is shown in Table 5. For a patient with a chronic pain diagnosis and an initial supply of 30 days or more, the predicted probability of progression to long-term use was $31.7 \%$, compared with an observed probability of $28.9 \%$. When the initial supply was less than 15 days, the predicted and observed probabilities decreased to $3.9 \%$ and $4.1 \%$, respectively. Predictive performance of all other combinations of variables is presented in Appendix 3 (available at www.cmajopen.ca/content/9/1/E96/suppl/DC1).

\section{Interpretation}

In this population of community-dwelling adults without cancer, several factors were associated with long-term use of prescription opioids, 4 of which are immediately modifiable at the point of care: long-acting opioids at initiation, a first filled opioid prescription of 15 days or more, initial dose of $90 \mathrm{MME} /$ day or more, and concomitant administration of multiple opioids. Health care providers should be aware of the profiles of patients at greatest risk for progressing to longterm use, including women 75 years of age or older, those using acetaminophen-codeine for 90 days or more in the preceding 12 months and those with a diagnosis associated with chronic pain. Prescriptions written by family physicians provided, on average, a week's duration of opioids and most frequently led to long-term use, which suggests that, at best, 
Table 3: Characteristics of initial opioid dispensing

\begin{tabular}{|c|c|c|c|}
\hline \multirow[b]{2}{*}{ Variable } & \multicolumn{2}{|c|}{ Group; no (\%) of participants } & \multirow[b]{2}{*}{$\begin{array}{c}\text { Difference in proportion, } \\
\%(95 \% \mathrm{Cl})\end{array}$} \\
\hline & $\begin{array}{l}\text { Long-term use } \\
\quad n=4172\end{array}$ & $\begin{array}{c}\text { Short-term use } \\
n=120492\end{array}$ & \\
\hline \multicolumn{4}{|c|}{ Opioid dispensed at index date } \\
\hline Morphine & $1132(27.1)$ & $39051(32.4)$ & $-5.3(-6.6$ to -3.9$)$ \\
\hline Codeine & 347 (8.3) & $10630(8.8)$ & $-0.5(-1.3$ to 0.0$)$ \\
\hline Hydromorphone & $1507(36.1)$ & $47729(39.6)$ & $-3.6(-5.0$ to -2.0$)$ \\
\hline Oxycodone & $797(19.1)$ & $21121(17.5)$ & $+1.6(0.4$ to 2.8$)$ \\
\hline Butorphanol & $1(0.0)$ & $3(0.0)$ & $0.0(0.0$ to 0.1$)$ \\
\hline Fentanyl & $264(6.3)$ & $235(0.2)$ & $+6.1(5.4$ to 6.9$)$ \\
\hline Meperidine & $33(0.8)$ & $1514(1.3)$ & $-0.5(-0.7$ to -0.1$)$ \\
\hline Pentazocine & $1(0.0)$ & $16(0.0)$ & $0.0(0.0$ to 0.1$)$ \\
\hline $\begin{array}{l}\text { Concomitant products } \\
\text { at index date }\end{array}$ & $90(2.2)$ & $193(0.2)$ & $+2.0(1.6$ to 2.5$)$ \\
\hline $\begin{array}{l}\text { Concomitant products } \\
\text { during index dispensing }\end{array}$ & $141(3.4)$ & $1252(1.0)$ & $+2.3(1.8$ to 3.0$)$ \\
\hline \multicolumn{4}{|l|}{ Mode of action } \\
\hline Short-acting & $3169(76.0)$ & $118885(98.7)$ & $-22.7(-24.0$ to -21.4$)$ \\
\hline Long-acting & $1003(24.0)$ & $1607(1.3)$ & $+22.7(21.4$ to 24.0$)$ \\
\hline \multicolumn{4}{|l|}{ Initial dose, MME/d } \\
\hline$<30$ & $2299(55.1)$ & $49381(41.0)$ & $+14.1(12.6$ to 15.7$)$ \\
\hline 30 to $<50$ & $1071(25.7)$ & 40304 (33.4) & $-7.8(-9.1$ to -6.4$)$ \\
\hline 50 to $<90$ & $563(13.5)$ & $26526(22.0)$ & $-8.5(-9.6$ to -7.4$)$ \\
\hline$\geq 90$ & $239(5.7)$ & $4281(3.6)$ & $+2.2(1.5$ to 2.9$)$ \\
\hline \multicolumn{4}{|l|}{ Initial supply, d } \\
\hline$<15$ & 2456 (58.9) & $112104(93.0)$ & $-34.2(-35.7$ to -32.7$)$ \\
\hline 15 to 29 & $584(14.0)$ & $5065(4.2)$ & +9.8 (8.8 to 10.9$)$ \\
\hline$\geq 30$ & $1132(27.1)$ & $3323(2.8)$ & $+24.4(23.0$ to 25.8$)$ \\
\hline \multicolumn{4}{|l|}{ Prescriber's specialty } \\
\hline Family medicine & 3567 (85.5) & 82913 (68.8) & $+16.7(15.6$ to 17.8$)$ \\
\hline Surgery & $177(4.2)$ & 23742 (19.7) & $-15.5(-16.1$ to -14.8$)$ \\
\hline Gynecology & $2(0.1)$ & $2014(1.7)$ & $-1.6(-1.7$ to -1.5$)$ \\
\hline Emergency medicine & $47(1.1)$ & $2927(2.4)$ & $-1.3(-1.6$ to -0.9$)$ \\
\hline Urology & $6(0.1)$ & $1802(1.5)$ & $-1.4(-1.5$ to -1.2$)$ \\
\hline Dentistry & $1(0.0)$ & $1573(1.3)$ & $-1.3(-1.4$ to -1.2$)$ \\
\hline Other† & $352(8.4)$ & $4886(4.1)$ & +4.4 (3.6 to 5.3$)$ \\
\hline Unknown & $20(0.5)$ & $635(0.5)$ & 0.0 (0.0 to 0.2$)$ \\
\hline \multicolumn{4}{|c|}{$\begin{array}{l}\text { Note: } \mathrm{Cl}=\text { confidence interval, } \mathrm{MME}=\text { morphine milligram equivalent. } \\
\text { *Positive difference values indicate that value for patients with long-term use was greater than value for patients with short-term } \\
\text { use; negative difference values indicate that value for patients with long-term use was less than value for patients with short-term } \\
\text { use. } \\
\text { †Other specialties included immunology, pathology, anesthesiology, cardiology, dermatology, gastroenterology, hematology, } \\
\text { pneumonology, internal medicine, physiatry, neurology, ophthalmology, otolaryngology, psychiatry, nuclear medicine, nephrology, } \\
\text { endocrinology, rheumatology and geriatrics. }\end{array}$} \\
\hline
\end{tabular}

initial opioid prescriptions should not exceed 7 days' supply. Although the US Centers for Disease Control and Prevention has advised against initiating therapy with a long-acting opioid, ${ }^{38} 24.0 \%$ of those for whom opioids were prescribed over the long term had received a long-acting opioid at the index date. These results are likely not explained by underascertainment of previous opioid usage, given that our analysis accounted for recent hospitalizations. Topical analgesics can 


\begin{tabular}{|c|c|c|}
\hline \multirow[b]{2}{*}{ Characteristic } & \multicolumn{2}{|c|}{ OR $(95 \% \mathrm{Cl})$} \\
\hline & Crude & Adjusted* \\
\hline \multicolumn{3}{|l|}{ Men, age, yr } \\
\hline 18 to 44 & 1.00 (Ref.) & 1.00 (Ref.) \\
\hline 45 to 54 & 2.10 (1.78 to 2.47$)$ & 1.44 (1.21 to 1.72$)$ \\
\hline 55 to 64 & 2.25 (1.92 to 2.64$)$ & $1.38(1.16$ to 1.64$)$ \\
\hline 65 to 74 & 1.59 (1.35 to 1.86$)$ & $1.12(0.94$ to 1.34$)$ \\
\hline 75 to 84 & $2.26(1.88$ to 2.71$)$ & 1.27 (1.03 to 1.55$)$ \\
\hline$\geq 85$ & 4.17 (3.28 to 5.32$)$ & 1.90 (1.44 to 2.49$)$ \\
\hline \multicolumn{3}{|l|}{ Women, age, yr } \\
\hline 18 to 44 & 1.00 (Ref.) & 1.00 (Ref.) \\
\hline 45 to 54 & 1.54 (1.20 to 1.98$)$ & $1.12(0.85$ to 1.47$)$ \\
\hline 55 to 64 & 1.55 (1.22 to 1.97$)$ & 1.31 (1.01 to 1.69$)$ \\
\hline 65 to 74 & 2.26 (1.79 to 2.85$)$ & $1.56(1.21$ to 2.00$)$ \\
\hline 75 to 84 & 3.01 (2.36 to 3.86$)$ & 1.99 (1.53 to 2.60$)$ \\
\hline$\geq 85$ & 3.16 (2.36 to 4.24$)$ & 2.14 (1.55 to 2.95$)$ \\
\hline \multicolumn{3}{|l|}{ Region of residence } \\
\hline Urban & 1.00 (Ref.) & 1.00 (Ref.) \\
\hline Semi-urban & $1.10(1.02$ to 1.18$)$ & 1.18 (1.08 to 1.28$)$ \\
\hline Rural & $1.11(1.02$ to 1.20$)$ & $1.23(1.13$ to 1.35$)$ \\
\hline \multicolumn{3}{|l|}{ Charlson Comorbidity Index } \\
\hline 0 & 1.00 (Ref.) & 1.00 (Ref.) \\
\hline 1 & $1.92(1.79$ to 2.06$)$ & $1.23(1.14$ to 1.34$)$ \\
\hline$\geq 2$ & 2.62 (2.38 to 2.87$)$ & $1.42(1.27$ to 1.59$)$ \\
\hline \multicolumn{3}{|l|}{ Opioid dispensed at index date } \\
\hline Morphine & 1.00 (Ref.) & 1.00 (Ref.) \\
\hline Codeine & $1.13(1.00$ to 1.27$)$ & $0.60(0.52$ to 0.69$)$ \\
\hline Hydromorphone & $1.09(1.01$ to 1.18$)$ & $1.26(1.15$ to 1.37$)$ \\
\hline Oxycodone & $1.30(1.19$ to 1.43$)$ & $1.24(1.12$ to 1.38$)$ \\
\hline Butorphanol & $11.50(1.20$ to 110.63$)$ & $5.35(0.47$ to 60.99$)$ \\
\hline Fentanyl & 38.75 (32.19 to 46.65$)$ & $1.17(0.93$ to 1.48$)$ \\
\hline Meperidine & $0.75(0.53$ to 1.07$)$ & 1.20 (0.83 to 1.72$)$ \\
\hline Pentazocine & $2.16(0.29$ to 16.27$)$ & $1.28(0.14$ to 11.35$)$ \\
\hline Concomitant products at index date & $16.09(12.44$ to 20.80$)$ & 1.34 (0.96 to 1.89$)$ \\
\hline Concomitant products during index dispensing & $3.33(2.79$ to 3.98$)$ & 2.10 (1.69 to 2.61$)$ \\
\hline \multicolumn{3}{|l|}{ Mode of action } \\
\hline Short-acting & 1.00 (Ref.) & 1.00 (Ref.) \\
\hline Long-acting & 23.42 (21.48 to 25.53$)$ & 6.02 (5.31 to 6.84$)$ \\
\hline \multicolumn{3}{|l|}{ Initial dose, MME/d } \\
\hline$<30$ & 1.00 (Ref.) & 1.00 (Ref.) \\
\hline 30 to $<50$ & $0.57(0.53$ to 0.61$)$ & 0.91 (0.83 to 0.99$)$ \\
\hline 50 to $<90$ & $0.46(0.42$ to 0.50$)$ & 0.85 (0.76 to 0.95$)$ \\
\hline$\geq 90$ & 1.20 (1.05 to 1.38$)$ & 1.24 (1.04 to 1.47$)$ \\
\hline \multicolumn{3}{|l|}{ Initial supply, d } \\
\hline$<15$ & 1.00 (Ref.) & 1.00 (Ref.) \\
\hline 15 to 29 & 5.26 (4.79 to 5.79$)$ & 2.22 (1.99 to 2.49$)$ \\
\hline$\geq 30$ & 15.55 (14.38 to 16.82$)$ & 4.22 (3.81 to 4.69$)$ \\
\hline
\end{tabular}




\begin{tabular}{|c|c|c|}
\hline \multirow[b]{2}{*}{ Characteristic } & \multicolumn{2}{|c|}{ OR $(95 \% \mathrm{Cl})$} \\
\hline & Crude & Adjusted \\
\hline \multicolumn{3}{|l|}{ Prescriber's specialty } \\
\hline Family medicine & 1.00 (Ref.) & 1.00 (Ref.) \\
\hline Surgery & 0.17 (0.15 to 0.20$)$ & 0.31 (0.27 to 0.37$)$ \\
\hline Gynecology & 0.02 (0.01 to 0.09 ) & 0.09 (0.02 to 0.36$)$ \\
\hline Emergency medicine & $0.37(0.28$ to 0.50$)$ & $0.67(0.50$ to 0.91$)$ \\
\hline Urology & 0.08 (0.04 to 0.17$)$ & $0.16(0.07$ to 0.36$)$ \\
\hline Dentistry & $0.02(0.00$ to 0.11$)$ & $0.06(0.01$ to 0.44$)$ \\
\hline Other & 0.08 (0.04 to 0.17$)$ & 1.34 (1.17 to 1.52$)$ \\
\hline Unknown & $0.73(0.47$ to 1.14$)$ & $0.77(0.47$ to 1.25$)$ \\
\hline \multicolumn{3}{|c|}{ Diagnoses or events associated with chronic or acute pain } \\
\hline Accident, fracture or surgery claims & 1.00 (Ref.) & 1.00 (Ref.) \\
\hline Diagnosis associated with chronic pain & $5.17(4.68$ to 5.71$)$ & 2.41 (2.16 to 2.69$)$ \\
\hline Other diagnosis associated with pain & $1.70(1.48$ to 1.94$)$ & $1.44(1.24$ to 1.66$)$ \\
\hline Hospital or ED claim in $7 \mathrm{~d}$ before index date & $1.24(1.07$ to 1.43$)$ & $1.21(1.04$ to 1.41$)$ \\
\hline Unknown diagnosis & 4.20 (3.76 to 4.68$)$ & 2.55 (2.26 to 2.88$)$ \\
\hline \multicolumn{3}{|l|}{ Psychiatric disorder† } \\
\hline Mood disorder & $1.76(1.54$ to 2.01$)$ & $1.02(0.86$ to 1.21$)$ \\
\hline Schizophrenia & $1.82(1.57$ to 2.11$)$ & $0.93(0.77$ to 1.12$)$ \\
\hline Anxiety disorder & 2.31 (2.04 to 2.62$)$ & $1.06(0.91$ to 1.23$)$ \\
\hline Other psychiatric disorder & 2.46 (2.23 to 2.72$)$ & $1.08(0.92$ to 1.26$)$ \\
\hline Dementia† & 4.15 (3.65 to 4.71$)$ & $1.46(1.20$ to 1.79$)$ \\
\hline Substance use disorder† & 1.85 (1.53 to 2.25$)$ & $1.50(1.20$ to 1.88$)$ \\
\hline \multicolumn{3}{|l|}{ Psychotropic drugs (in 12 mo before index date) } \\
\hline None & 1.00 (Ref.) & 1.00 (Ref.) \\
\hline Benzodiazepines & $2.99(2.81$ to 3.18$)$ & $1.57(1.45$ to 1.69$)$ \\
\hline Antipsychotics & $2.68(2.48$ to 2.91$)$ & 1.69 (1.53 to 1.88$)$ \\
\hline Antidepressants & $2.41(2.24$ to 2.60$)$ & $1.37(1.25$ to 1.50$)$ \\
\hline \multicolumn{3}{|l|}{ NSAIDs (in 12 mo before index date) } \\
\hline None & 1.00 (Ref.) & 1.00 (Ref.) \\
\hline Short-term $(<90 \mathrm{~d})$ & $1.30(1.21$ to 1.41$)$ & $1.23(1.13$ to 1.34$)$ \\
\hline Long-term ( $\geq 90 \mathrm{~d})$ & 3.86 (3.55 to 4.21$)$ & $1.96(1.77$ to 2.18$)$ \\
\hline \multicolumn{3}{|c|}{ Prescribed acetaminophen (in 12 mo before index date) } \\
\hline None & 1.00 (Ref.) & 1.00 (Ref.) \\
\hline Short-term $(<90 \mathrm{~d})$ & $2.43(2.21$ to 2.67$)$ & $1.32(1.18$ to 1.47$)$ \\
\hline Long-term ( $\geq 90 \mathrm{~d})$ & $5.41(5.01$ to 5.84$)$ & 2.05 (1.86 to 2.25$)$ \\
\hline \multicolumn{3}{|c|}{ Prescribed acetaminophen-codeine (in 12 mo before index date) } \\
\hline None & 1.00 (Ref.) & 1.00 (Ref.) \\
\hline Short-term $(<90 \mathrm{~d})$ & 2.01 (1.81 to 2.22$)$ & $1.44(1.28$ to 1.62$)$ \\
\hline Long-term ( $\geq 90 \mathrm{~d})$ & $15.57(12.87$ to 18.81$)$ & $6.30(4.99$ to 7.96$)$ \\
\hline \multicolumn{3}{|l|}{ Gabapentinoid (in 12 mo before index date) } \\
\hline None & 1.00 (Ref.) & 1.00 (Ref.) \\
\hline Short-term $(<90 \mathrm{~d})$ & 3.88 (3.45 to 4.37$)$ & 1.84 (1.61 to 2.12$)$ \\
\hline Long-term ( $\geq 90 \mathrm{~d})$ & 5.19 (4.74 to 5.68$)$ & $2.02(1.81$ to 2.25$)$ \\
\hline \multicolumn{3}{|c|}{$\begin{array}{l}\text { Note: } \mathrm{Cl}=\text { confidence interval, } \mathrm{ED}=\text { emergency department, } \mathrm{MME}=\text { morphine milligram equivalent, } \mathrm{OR}=\text { odds ratio, Ref. = referenc } \\
\text { category. } \\
\text { *Adjusted for all other variables listed in this table. } \\
\text { †For psychiatric disorders, dementia and substance use disorder, the reference category was absence of the disorder. }\end{array}$} \\
\hline
\end{tabular}




\section{Research}

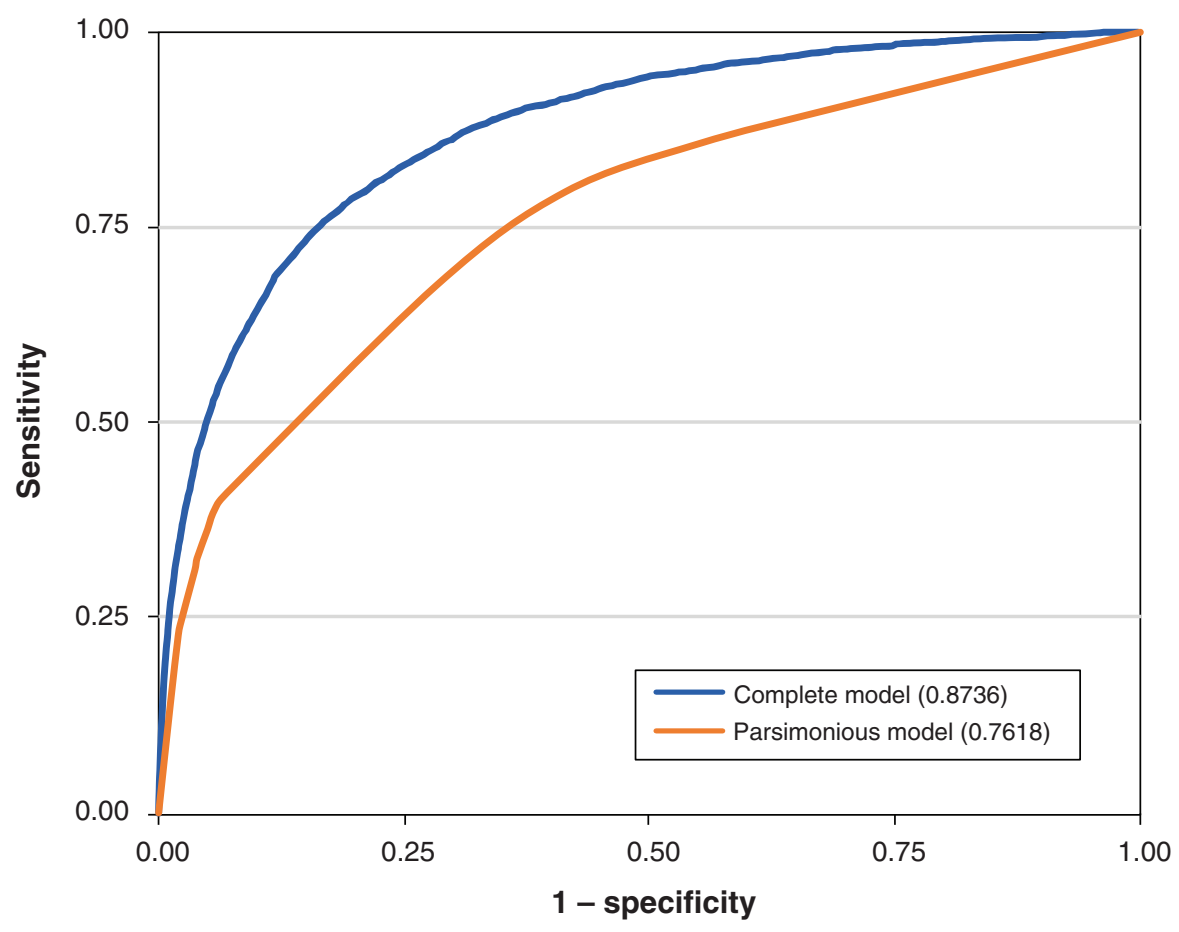

Figure 1: Receiver operating characteristic curves for the complete and parsimonious models. The complete model includes all covariables listed in Table 4, and the parsimonious model includes only duration of the initial prescription and previous diagnosis associated with chronic pain. The area under each curve is shown within parentheses in the legend.

\begin{tabular}{|c|c|c|}
\hline \multirow[b]{2}{*}{ Variable } & \multicolumn{2}{|c|}{ OR $(95 \% \mathrm{Cl})$} \\
\hline & Crude & Adjusted* $^{*}$ \\
\hline \multicolumn{3}{|l|}{ Initial supply, d } \\
\hline$<15$ & 1.00 (Ref.) & 1.00 (Ref.) \\
\hline 15 to 29 & 5.26 (4.79 to 5.79$)$ & 4.20 (3.81 to 4.62$)$ \\
\hline$\geq 30$ & 15.55 (14.38 to 16.82$)$ & $11.44(10.55$ to 12.41$)$ \\
\hline \multicolumn{3}{|l|}{$\begin{array}{l}\text { Diagnoses or events associated with chronic } \\
\text { or acute pain }\end{array}$} \\
\hline Accident, fracture or surgery claims & 1.00 (Ref.) & 1.00 (Ref.) \\
\hline Diagnosis associated with chronic pain & 5.17 (4.68 to 5.71$)$ & 3.65 (3.30 to 4.05$)$ \\
\hline Other diagnosis associated with pain & $1.70(1.48$ to 1.94$)$ & 1.59 (1.38 to 1.82$)$ \\
\hline $\begin{array}{l}\text { Hospital or ED claim for unknown } \\
\text { diagnosis in } 7 \mathrm{~d} \text { before index date }\end{array}$ & $1.24(1.07$ to 1.43$)$ & 1.19 (1.03 to 1.37$)$ \\
\hline Unknown diagnosis & 4.20 (3.76 to 4.68$)$ & 2.85 (2.55 to 3.19$)$ \\
\hline \multicolumn{3}{|c|}{$\begin{array}{l}\text { Note: } \mathrm{Cl}=\text { confidence interval, } \mathrm{ED}=\text { emergency department, } \mathrm{OR}=\text { odds ratio, Ref. = reference category. } \\
\text { *Adjusted for all other variables listed in this table (i.e., initial days' supply and diagnoses or events associated with chronic or } \\
\text { acute pain). }\end{array}$} \\
\hline
\end{tabular}


be proposed for such patients. Unfortunately, these formulations are not covered by the Quebec public drug plan.

This study's $3.3 \%$ progression rate to long-term opioid use was similar to estimates from the US $(3.3 \%),{ }^{18}$ Australia $(2.6 \%),{ }^{39}$ Germany $(1.3 \%)^{40}$ and Norway $(3.0 \%) .{ }^{41}$ Higher progression rates were found across Canadian provinces, ranging from 9.9 to $17.7 \%,{ }^{42}$ likely because of differences in the definition of long-term use. Those who progressed to long-term use accounted for $51.1 \%$ of total MMEs dispensed to our cohort, which is lower than the $87 \%$ found in British Columbia ${ }^{26}$ but consistent with data from other studies. ${ }^{43-46}$

Predictors of long-term opioid use were also found in previous studies, such as chronic pain ${ }^{43}$ history of substance use disorder or dementia, ${ }^{15}$ prior use of psychotropic drugs or analgesics, ${ }^{39,45,47}$ use of hydromorphone or oxycodone at initiation, concomitant opioids and initial daily dose of $90 \mathrm{MME}$ or more.$^{46}$ In the current study, patients receiving at least $90 \mathrm{MME} /$ day at the index date had mostly initiated opioid therapy with short-acting hydromorphone or oxycodone and had not been hospitalized before the index date. Overall, $24.1 \%$ of those with long-term prescribing of opioids and $15.0 \%$ of those with short-term prescribing did not have any previous pain diagnoses, surgery or recent hospital admission. An Ontario study, also using claims data, found a similar proportion of patients without these factors (12\%)..$^{34}$ To our knowledge, the development of a predictive model for long-term use was previously attempted in only 1 study, in which long-acting opioid and use of tramadol were leading predictors. ${ }^{45}$

In this study, the large number of patients classified as having long-term use of prescription opioids allowed for the inclusion of all available variables in the regression model, which is a strength for assessing potential risk factors.

\section{Limitations}

The Quebec drug claims database does not record inpatient medication use. We mitigated this limitation by excluding patients admitted for $70 \%$ or longer of the follow-up period and, for the other patients, by taking into account opioid dispensing before and after admission. The alternative (i.e., excluding hospitalized patients) would have introduced selection bias.

We did not examine use of tramadol, a predictor of longterm opioid use, ${ }^{43,45}$ because it was not covered during the study period.

Absence of indication is a limitation of studies conducted using claims databases. The categories developed a priori were partially based on clinical expert opinion. Incomplete recording of diagnoses in claims may explain the substantial frequency of patients with no potential indications for opioids, but likely does not explain the difference between those with long-term and short-term prescribing of opioids.

The public drug plan in Quebec excludes residents with private coverage plans, those in hospital and those in longterm care. This limits the generalizability of our results, although the proportion of patients with long-term use was consistent with that of previous studies.
The area under the curve assesses only model discrimination. One area for future study would be model calibration. By selecting a parsimonious model that met the area under the curve threshold of 0.70 , we excluded models with greater area under the curve and hence, better predictive performance. However, we were aiming to develop a simple tool that could be used to alert clinicians to patient profiles with a higher likelihood of transition to long-term use and to underscore risky prescribing behaviours, such as initial prescriptions with duration of 1 month or longer. Furthermore, ORs provide complementary insights to the area under the curve, which is why elements of both types of analysis were displayed.

Given the timelines for data acquisition and study conduct, these findings may not reflect contemporary practices.

\section{Conclusion}

This study identified factors associated with long-term use of prescription opioids. Health care providers can help to limit the progression to long-term opioid use by ensuring that initial prescriptions do not exceed 7 days or the equivalent of $90 \mathrm{MME} /$ day without reassessment and by avoiding long-acting formulations and concomitant opioids. Regular re-evaluation of opioid prescriptions should be performed, with simple questions about type and intensity of pain, to prevent unnecessary dose titration. Thorough, periodic re-evaluations of opioid prescriptions by health care providers (perhaps with introduction of non-opioid alternatives, according to existing guidelines) might help limit long-term opioid use.

\section{References}

1. Duarte R, Raphael J. The pros and cons of long-term opioid therapy. 7 Pain Palliat Care Pharmacother 2014;28:308-10.

2. Ballantyne JC. "Safe and effective when used as directed": the case of chronic use of opioid analgesics. 7 Med Toxicol 2012;8:417-23.

3. Burgess HJ, Siddiqui A, Burgess FW. Long-term opioid therapy for chronic pain and the risk of opioid addiction. R I Med f (2013) 2014;97:25-8.

4. Häuser W, Bock F, Engeser P, et al. Long-term opioid use in non-cancer pain. Dtsch Arztebl Int 2014;111:732-40.

5. Noble M, Tregear SJ, Treadwell JR, et al. Long-term opioid therapy for chronic noncancer pain: a systematic review and meta-analysis of efficacy and safety. 7 Pain Symptom Manage 2008;35:214-28.

6. Special Advisory Committee on the Epidemic of Opioid Overdoses. National report: apparent opioid-related deaths in Canada (fanuary 2016 to Fune 2017) [web-based report]. Ottawa: Public Health Agency of Canada; 2018. Available: www.canada.ca/en/public-health/services/publications/healthy-living/ national-report-apparent-opioid-related-deaths-released-march-2018.html (accessed 2019 June 13).

7. Shemilt M, Langlois E, Dubé MA, et al. Décès attribuables aux intoxications par opioïdes au Québec, 2000 à 2012: mise à jour 2013-2016. Québec: Institut national de santé publique du Québec; 2017.

8. Pan-Canadian trends in the prescribing of opioids and benzodiazepines, 2012 to 2017. Ottawa: Canadian Institute for Health Information; 2018.

9. Moride Y, Lemieux-Uresandi D, Castillon G, et al. A systematic review of interventions and programs targeting appropriate prescribing of opioids. Pain Physician 2019;22:229-40.

10. Portrait de l'usage des opioïdes chez les personnes couvertes par le régime public d'assurance médicaments du Québec. Québec: Institut national d'excellence en santé et en services sociaux; 2018.

11. Schieber LZ, Guy GP Jr, Seth P, et al. Trends and patterns of geographic variation in opioid prescribing practices by state, United States, 2006-2017. ZAMA Netw Open 2019;2:e190665.

12. Busse JW, Craigie S, Juurlink DN, et al. Guideline for opioid therapy and chronic noncancer pain. CMA7 2017;189:E659-66.

13. Alghnam S, Castillo R. Traumatic injuries and persistent opioid use in the USA: findings from a nationally representative survey. Inj Prev 2017;23:87-92.

14. Anciano Granadillo V, Cancienne JM, Gwathmey FW, et al. Perioperative opioid analgesics and hip arthroscopy: trends, risk factors for prolonged use, and complications. Artbroscopy 2018;34:2359-67. 
15. Inacio MCS, Hansen C, Pratt NL, et al. Risk factors for persistent and new chronic opioid use in patients undergoing total hip arthroplasty: a retrospective cohort study. BM7 Open 2016;6:e10664.

16. Bedson J, Chen Y, Hayward RA, et al. Trends in long-term opioid prescribing in primary care patients with musculoskeletal conditions: an observational database study. Pain 2016;157:1525-31.

17. Chui PW, Bastian LA, DeRycke E, et al. Dual use of Department of Veterans Affairs and Medicare benefits on high-risk opioid prescriptions in veterans aged 65 years and older: insights from the VA musculoskeletal disorders cohort. Health Serv Res 2018;53(Suppl 3):5402-18.

18. Bertenthal D, Yaffe K, Barnes DE, et al.; Chronic Effects of Neurotrauma Consortium Study Group. Do postconcussive symptoms from traumatic brain injury in combat veterans predict risk for receiving opioid therapy for chronic pain? Brain Inj 2018;32:1188-96.

19. Dobscha SK, Morasco BJ, Duckart JP, et al. Correlates of prescription opioid initiation and long-term opioid use in veterans with persistent pain. Clin 7 Pain 2013;29:102-8.

20. Hudson TJ, Painter JT, Martin BC, et al. Pharmacoepidemiologic analyses of opioid use among OEF/OIF/OND veterans. Pain 2017;158:1039-45.

21. Mudumbai SC, Oliva EM, Lewis ET, et al. Time-to-cessation of postoperative opioids: a population-level analysis of the Veterans Affairs health care system. Pain Med 2016;17:1732-43.

22. La RAMQ en quelques chiffres. Québec: Régie de l'assurance maladie du Québec. Available: www.ramq.gouv.qc.ca/en/node/89526 (accessed 2020 Aug. 6).

23. International classification of diseases: [9th] ninth revision, basic tabulation list with alphabetic index. Geneva: World Health Organization; 1978.

24. Von Korff M, Saunders K, Ray GT, et al. De facto long-term opioid therapy for noncancer pain. Clin 7 Pain 2008;24:521-7.

25. Calcaterra SL, Yamashita TE, Min SJ, et al. Opioid prescribing at hospital discharge contributes to chronic opioid use. 7 Gen Intern Med 2016;31:478-85.

26. Smolina K, Gladstone EJ, Rutherford K, et al. Patterns and trends in longterm opioid use for non-cancer pain in British Columbia, 2005-2012. Can $\mathcal{F}$ Public Health 2016;107:e404-9.

27. Hooten WM, St Sauver JL, McGree ME, et al. Incidence and risk factors for progression from short-term to episodic or long-term opioid prescribing: a population-based study. Mayo Clin Proc 2015;90:850-6.

28. Charlson ME, Pompei P, Ales KL, et al. A new method of classifying prognostic comorbidity in longitudinal studies: development and validation. 7 Chronic Dis 1987;40:373-83.

29. Chou R, Turner JA, Devine EB, et al. The effectiveness and risks of long-term opioid therapy for chronic pain: a systematic review for a National Institutes of Health Pathways to Prevention Workshop. Ann Intern Med 2015;162:276-86.

30. Edlund MJ, Martin BC, Fan MY, et al. Risks for opioid abuse and dependence among recipients of chronic opioid therapy: results from the TROUP study. Drug Alcobol Depend 2010;112:90-8.

31. Voon P, Karamouzian M, Kerr T. Chronic pain and opioid misuse: a review of reviews. Subst Abuse Treat Prev Policy 2017;12:36.

32. Turk DC, Swanson KS, Gatchel RJ. Predicting opioid misuse by chronic pain patients: a systematic review and literature synthesis. Clin 7 Pain 2008;24:497-508.

33. Sullivan MD, Edlund MJ, Zhang L, et al. Association between mental health disorders, problem drug use, and regular prescription opioid use. Arch Intern Med 2006;166:2087-93

34. Pasricha SV, Tadrous $M$, Khuu $W$, et al. Clinical indications associated with opioid initiation for pain management in Ontario, Canada: a populationbased cohort study. Pain 2018;159:1562-8.

35. Table pratique de conversion des opioides de palier II et III. Toulouse (France): Centre Hospitalier Universitaire de Toulouse; 2016. Available: www.chu-toulouse.fr/ IMG/pdf/12_table_conversion_palier_ii_et_iii_v6.pdf(accessed 2020 Aug. 6).

36. Hanley JA, McNeil BJ. The meaning and use of the area under a receiver operating characteristic (ROC) curve. Radiology 1982;143:29-36.

37. DeLong ER, DeLong DM, Clarke-Pearson DL. Comparing the areas under two or more correlated receiver operating characteristic curves: a nonparametric approach. Biometrics 1988;44:837-45

38. Dowell D, Haegerich TM, Chou R. CDC guideline for prescribing opioids for chronic pain - United States, 2016. MMWR Recomm Rep 2016;65:1-49.

39. Lalic S, Gisev N, Bell JS, et al. Predictors of persistence prescription opioid analgesic use among people without cancer in Australia. Br 7 Clin Pharmacol 2018;84:1267-78.
40. Marschall U, L'hoest H, Radbruch L, et al. Long-term opioid therapy for chronic non-cancer pain in Germany. Eur 7 Pain 2016;20:767-76.

41. Fredheim OM, Mahic M, Skurtveit S, et al. Chronic pain and use of opioids: a population-based pharmacoepidemiological study from the Norwegian prescription database and the Nord-Trøndelag health study. Pain 2014;155:1213-21.

42. National Prescription Drug Utilization Information System (NPDUIS). Utilization of prescription opioids in Canada's public drug plans, 2006/07 to 2012/13. Ottawa: Patented Medicine Prices Review Board; 2014.

43. Shah A, Hayes CJ, Martin BC. Factors influencing long-term opioid use among opioid naive patients: an examination of initial prescription characteristics and pain etiologies. 7 Pain 2017;18:1374-83.

44. Shah A, Hayes CJ, Martin BC. Characteristics of initial prescription episodes and likelihood of long-term opioid use - United States, 2006-2015. MMWR Morb Mortal Wkly Rep 2017;66:265-9.

45. Thornton JD, Dwibedi N, Scott V, et al. Predictors of transitioning to incident chronic opioid therapy among working-age adults in the United States. Am Health Drug Benefits 2018;11:12-21.

46. Deyo RA, Hallvik SE, Hildebran C, et al. Association between initial opioid prescribing patterns and subsequent long-term use among opioid-naive patients: a statewide retrospective cohort study. $\mathcal{F}$ Gen Intern Med 2017;32:21-7.

47. Birke H, Ekholm O, Sjøgren P, et al. Long-term opioid therapy in Denmark: a disappointing journey. Eur 7 Pain 2017;21:1516-27.

Affiliations: Faculty of Pharmacy (Béliveau, Castilloux, Tannenbaum, Vincent, Moride), Université de Montréal; Institut universitaire de gériatrie de Montréal (Tannenbaum); Department of Pharmacy (Vincent), Institut universitaire en santé mentale de Montréal; Division of Clinical Epidemiology (Soares de Moura, Bernatsky), McGill University, Montréal, Que.; Rutgers, The State University of New Jersey (Moride), New Brunswick, NJ

Contributors: Yola Moride and Audrey Béliveau were the main contributors to conception and design of the study and to acquisition, analysis and interpretation of the data. Cara Tannenbaum and Philippe Vincent contributed to defining the scope of the study, developing the study protocol and interpreting the study findings, especially as they relate to the clinical implications. Cristiano Soares de Mouras and Sasha Bernatsky contributed to developing the study protocol, performing the analysis and interpreting the findings. Anne-Marie Castilloux planned and conducted all data management activities, as well as the cohort programming. Audrey Béliveau developed the first draft of the manuscript, and Yola Moride developed all subsequent drafts. All of the authors revised the manuscript for important intellectual content, approved the final version for publication and agreed to be accountable for the work. Yola Moride was the senior investigator and supervised all components of the study. At the time of this study, Audrey Béliveau was a student at the Universite de Montréal, and this work was part of her MSc thesis.

Funding: This project was funded by the Drug Safety and Effectiveness Network through Canadian Institutes for Health Research grant DES-149322.

Content licence: This is an Open Access article distributed in accordance with the terms of the Creative Commons Attribution (CC BY-NCND 4.0) licence, which permits use, distribution and reproduction in any medium, provided that the original publication is properly cited, the use is noncommercial (i.e., research or educational use), and no modifications or adaptations are made. See: https://creativecommons.org/licenses/ by-nc-nd/4.0/

Data sharing: The study data are not available to others.

Supplemental information: For reviewer comments and the original submission of this manuscript, please see www.cmajopen.ca/content/9/1/ E96/suppl/DC1. 